\title{
Comparative pathogenicity of bovine herpesvirus 1 (BHV-1) subtypes 1 (BHV-1.1) and 2a (BHV-1.2a)
}

\author{
Fernando Rosado Spilki², Paulo Augusto Esteves², Marcelo de Lima ${ }^{4}$, Ana Cláudia \\ Franco², Cláudio Chiminazzo², Eduardo Furtado Flores ${ }^{4}$, Rudi Weiblen ${ }^{4}$, David \\ Driemeier ${ }^{5}$ and Paulo Michel Roehe ${ }^{2,3^{*}}$
}

\begin{abstract}
Spilki F.R, Esteves P.A., Lima M., Franco A.C., Chiminazzo C., Flores E.F., Weiblen R., Driemeier D. \& Roehe P.M. 2004. Comparative pathogenicity of bovine herpesviruses type 1 (BHV-1) subtypes 1 (BHV-1.1) and 2a (BHV-1.2a). Pesquisa Veterinária Brasileira 24(1):43-49. Centro de Pesquisas Desidério Finamor, Fepagro Saúde Animal, Cx. Postal 47, Eldorado do Sul, RS92990-000, Brazil. E-mail: proehe@ ufrgs.br

The study aimed to examine the capacity of two bovine herpesvirus type 1 (BHV-1) isolates of different subtypes (EVI 123/96, BHV-1.1; SV265/98, BHV-1.2a) to induce respiratory disease in calves. These two isolates are representative of the BHV-1 subtypes prevalent in Brazil. Viral subtypes were confirmed by monoclonal antibody analysis and by restriction enzyme digestion of viral genomes. The viruses were inoculated intranasally into seven 3 months old calves (four with BHV-1.1, three with BHV-1.2a). Three other calves of identical age and condition were kept as uninfected controls. In both groups of infected calves, the clinical signs observed were consistent with typical infectious bovine rhinothracheitis (IBR), including pyrexia, apathy, anorexia, nasal and ocular mucopurulent discharges, erosions on the nasal mucosa, conjunctivitis, lachrymation, redness of nasal mucosa, dyspnoea, coughing, tracheal stridor and enlargement of retropharingeal, submandibular and cervical lymphnodes. No significant differences were observed between the clinical scores attributed to both groups. Virus shedding in nasal and ocular secretions were also similar, apart from a significant difference in nasal virus shedding on day 1 to 3 post-inoculation, which was higher for BHV-1.1 than for BHV1.2a. Following corticosteroid induced reactivation of the latent infection, recrudescence of clinical signs was also observed, with no significant differences on both groups. It was concluded that both subtypes BHV-1.1 and BHV-1.2a were able to induce clinically undistinguishable respiratory disease in calves, either subsequent to a primary infection or following reactivation.
\end{abstract}

INDEX TERMS: Infectious bovine rhinotracheitis, IBR, BHV-1.1, BHV-1.2a, subtypes, pathogenicity.

RESUMO.- [Avaliação comparativa da patogenicidade de herpesvírus bovinos tipo 1 (BHV-1) subtipos 1 (BHV-1.1) e 2a (BHV-1.2a).] 0 presente estudo teve como objetivo examinar a capacidade de duas amostras de herpesvírus bovino tipo 1 (BHV-1) de diferentes subtipos (amostra EVI 123/96: BHV-1.1; amos-

\footnotetext{
${ }^{1}$ Recebido em 2 de abril de 2003.

Aceito para publicação em 20 de dezembro de 2003.

${ }^{2}$ Centro de Pesquisas Veterinárias Desidério Finamor - Fepagro Saúde Animal, Estrada do Conde 6000, Cx. Postal 47, Eldorado do Sul, RS 92990-000, Brazil.

${ }^{3}$ Depto Microbiologia, Laboratório de Virologia, UFRGS, Porto Alegre, RS 90050-170, Brazil. *Corresponding author. E-mail: proehe@ ufrgs.br

${ }^{4}$ Depto Medicina Veterinária Preventiva, UFSM, Santa Maria, RS 97105-900.

${ }^{5}$ Depto Patologia Clínica, Faculdade de Veterinária, UFRGS.
}

tra SV265/98: BHV-1.2a) de induzir doença respiratória em bovinos. Estas duas amostras são representativas de subtipos de BHV1 prevalentes no Brasil. Os subtipos das amostras foram confirmados por análises com anticorpos monoclonais e com enzimas de restrição. As amostras foram inoculadas por via intranasal em sete bezerros de três meses de idade (quatro com BHV-1.1, três com BHV-1.2a), soronegativos para BHV-1, sendo outros três animais mantidos como controles não infectados. Nos dois grupos de animais inoculados, os sinais clínicos observados foram consistentes com o quadro de rinotraqueíte infecciosa bovina (IBR), incluindo febre, apatia, anorexia, descargas mucopurulentas nasais e oculares, conjuntivite, erosões e hiperemia na mucosa nasal, dispnéia, tosse, estridor traqueal e aumento dos linfonodos retrofarín-geos, submandibulares e cervicais. Não foram observadas diferenças significativas entre os escores clínicos atribuídos 
aos animais nos dois grupos. Igualmente, foram similares as quantidades de vírus re-isoladas dos animais infectados, à exceção de uma diferença significativa na disseminação de vírus pelas secreções nasais, a qual foi maior nos animais infectados com BHV-1.1 nos dias 1 a 3 pós-inoculação. Após reativação induzida por corticosteróides, foi observado recrudescimento dos sinais clínicos, os quais foram também similares em ambos os grupos. Em conclusão, as amostras de BHV-1 dos subtipos 1 e 2a não apresentaram diferenças significativas em sua patogenicidade sobre 0 trato respiratório nos animais inoculados, tanto após a infecção primária como após a reativação.

TERM OS DE INDEXAÇÃO: Rinotraqueíte infecciosa bovina, IBR, BHV1.1, BHV-1.2 ${ }^{\mathrm{a}}$, subtipos, patogenicidade.

\section{INTRODUCTION}

Bovine herpesvirus type 1 (BHV-1), an alphaherpesvirus, is an important pathogen for cattle, causing severe economical losses to cattle industry (Turin et al. 1999). Three BHV-1 subtypes, 1 (BHV-1.1), 2a (BHV-1.2a) and 2b (BHV-1.2b) have been recognized with basis on antigenic and genomic analyses (Metzler et al. 1985). Subtypes 1 and 2b have been associated to different signs of disease or different degrees of pathogenicity. BHV-1.1 refers to the "classical" viruses which have been associated to infectious bovine rhinotracheitis (IBR). This subtype has often been isolated from the respiratory tract as well as from abortions, and is prevalent in many countries in Europe as well as in the Americas (Edwards et al. 1990, Souza et al. 2002). BHV-1.2a, on its turn, has been associated to a broad range of clinical manifestations on both the respiratory and genital tracts such as IBR, infectious pustular vulvovaginitis (IPV) or balanopostitis (IPB), as well as abortions (Oirschot 1995). BHV-1.2a is highly prevalent in Brazil; it was present in Europe before the decade of 1970; after that, it became rare in that continent (Oirschot 1995, D'Arce et al. 2002). BHV-1.2b, on its turn, has been associated to respiratory disease as well as to IPV/IPB. Therefore, subtype $2 \mathrm{~b}$ has not been related to abortion (Oirschot 1995) and has been considered less pathogenic for the respiratory tract than BHV-1.1 (Edwards et al. 1990). Subtype $2 \mathrm{~b}$ has been frequently isolated in Australia and Europe (Edwards et al. 1990), but is uncommon in Brazil where, to date, only one virus of this subtype has been so far isolated.

Differences in virulence among BHV-1 subtypes that affect the respiratory tract have also been reported. BHV-1.1 isolates are more pathogenic than BHV-1.2b (Msolla et al. 1983a, Edwards et al. 1990). However, no comparative evaluation of BHV-1.2a pathogenicity on the respiratory tract has been made to date, probably in view of the low prevalence of this subtype in Europe and North America. As BHV-1.1 and BHV-1.2a have often been associated to respiratory disease and are highly prevalent in Brazil, the present study was carried out to examine the virulence of two recent Brazilian isolates of BHV-1.1 and BHV-1.2a following intranasal inoculation in calves.

\section{MATERIALS AND METHODS}

Viruses and cells. Madin Darby bovine kidney cells (MDBK; ATCC CCL22) were used throughout. Cells were cultured in Eagle's
Minimal Essential Medium (E-MEM) supplemented with $6 \%$ foetal bovine serum (FBS) and enrofloxacin (Baytril, final concentration 10 $\mathrm{mg} / \mathrm{L}$ ). The BHV-1.1 strain EVI 123/98 and BHV-1.2a SV 265/96 were used for comparative inoculations. These two viruses were isolated from outbreaks of IBR in Southern Brazil in 1998 and 1996, respectively (D'Arce et al. 2002 ). Both were multiplied in MDBK cells to prepare stocks with approximately $10^{8.3} 50 \%$ tissue culture infective doses per $\mathrm{mL}\left(\mathrm{TCID}_{50}\right)$. Virus stocks were clarified by centrifugation (2000 $\mathrm{x} \mathrm{g}$ ) and stored at $-70{ }^{\circ} \mathrm{C}$ until use. Viruses and cells were proven free of bovine viral diarrhoea virus contamination by immunoperoxidase (Roehe et al. 1991).

Genomic and antigenic analyses. Genomic analyses were performed by restriction endonuclease digestion. Viral DNA was cleaved with enzymes BamHI, BstEll, EcoRI, Hind III and Pstl, as described (D'Arce et al. 2002). Antigenic analyses with monoclonal antibodies (Mabs) were carried out by immunoperoxidase monolayer assays (IPMAs) on virus multiplied in microtitre plates, as described elsewhere (Souza et al. 2002). In addition, a differential IPMA was performed with a Mab (Mab 71) that recognizes a specific epitope on BHV-1 glycoprotein C ( $\mathrm{gC}$ ) and does not react with BHV-1.2a (Rijsewijk et al. 1999). The differential IPMA followed essentially the method described previously (Souza et al. 2002), except that Mab 71 was used as primary antibody, followed by an anti-mouse peroxidase/lgG conjugate (DAKO).

Inoculation of calves. Ten, three to four months old calves, seronegative for BHV-1 (as determined by serum neutralization tests and ELISAs), were purchased from a local beef farm. Calves were randomly alloted into three groups (BHV-1.1, four calves; BHV-1.2a, three calves; three control calves) and kept in identical isolation units with controlled environmental temperature and air supply. The calves were fed with forage and water ad libitum and supplemented with concentrate. After twelve days for adaptation in the isolation units, each calf was inoculated with $10^{9} \mathrm{TCID}_{50}$ of either BHV-1.1 or BHV$1.2 \mathrm{a}$, in a volume of $8 \mathrm{~mL}$, applied with the aid of an intranasal spray, divided $(2 \times 4 \mathrm{ml})$ and inoculated into each nostril. The control group was mock infected with sterile culture medium.

Clinical assessment. The calves were examined daily from day 12 before inoculation until day 14 post-infection (pi). Respiratory rates and rectal temperatures were recorded. Clinical scores were obtained by a scoring method based on that described by Collie (1992), modified by attributing arbitrary points to different signs of disease, based on our previous experience with BHV-1 inoculations. Signs considered more indicative of the calve's well-being were recorded on a higher scale. Thus, apathy, anorexia, dyspnoea and unusual stridors at auscultation were scaled up to 100, whereas nasal and ocular secretions, conjuntivitis, presence of erosions on the nasal mucosae, enlargement of lymph nodes and cough were scaled up to 10 . Temperature rates (TR) were included on individual scores using the formula:

$T R=100 \times$ (calf's temperature on each day - calf's mean temperature on the 12 days prior to inoculation).

\section{A mean clinical score was calculated daily for each group.}

Reactivation. Starting from day 168 pi, new clinical scores were determined for 12 days, as above. Aiming virus reactivation, from day $180 \mathrm{pi}$, calves were treated with $0.1 \mathrm{mg}$ per $\mathrm{kg}$ of body weight of dexamethasone for 5 consecutive days. Clinical examinations and scoring were performed again from the beginning of the corticosteroid administration up to day 194 pi.

Virological and serological examinations. Samples for virus isolation were collected on day 12 previous to inoculation, on the day of virus inoculation (day 0) and daily from days 1 to 14 post- 
inoculation (pi); samples were also collected on day 5 before to 14 days after the administration of dexamethasone. Nasal and ocular swabs were eluted in $2 \mathrm{~mL}$ of sample medium (E-MEM supplemented with 10 times the usual concentration of antibiotics and $2 \%$ FBS for one hour at room temperature. The samples were vigorously shaken, the swabs removed, drained, the medium clarified by low speed centrifugation and stored at $-70^{\circ} \mathrm{C}$ until use. Tissues were processed as described below. Virus isolation and titrations of recovered viruses were performed following standard protocols (Roehe 1991). Infectious titres were calculated and expressed as $\log _{10} T C I D_{50}$ per $\mathrm{mL}$ of nasal or ocular fluid or per grams of tissue. Serum samples were collected by jugular venipuncture on days $0,7,14$ and 30 days pi and 0,7 and 14 post-reactivation (pr). Sera were tested in serial twofold dilutions in a standard BHV-1 neutralizing antibody test with 1 hour incubation of the serum/virus mixture followed by incubation at $37^{\circ} \mathrm{C}$ for five days (House \& Baker 1971), against 100 TCID $_{50}$ of each of the two virus subtypes.

Post-mortem examinations. Calves that died were submitted to necropsy and fragments of tissues for virus isolation were collected from nasal mucosae, nasal hornets, trachea, tonsils, cervical and mediastinic lymph nodes, lung, brain, trigeminal ganglia, liver, spleen, adrenal glands and kidneys. Ten per cent (w/v) suspensions were prepared in MEM, filtered through $22 \mathrm{~nm}$ filters and inoculated onto MDBK monolayers following standard procedures (Roehe 1991). Routine bacteriological examinations were also performed on all specimens. Histopathological analysis was performed on buffered formalin paraffin embedded tissues; immuno-histochemical analyses were also performed following routine protocols.

Confirmation of the identity of viruses recovered from calves. To confirm the identity of the viruses recovered from inoculated calves and to ensure that no cross-contamination has taken place, the differential IPMA described above was carried out on all successful virus recovery attempts.

Statistical analysis. The results were statistically examined by analysis of variance (ANOVA); the least significance difference for $p=$ 0.05 was determined. Comparisons were made within the groups from day to day and between groups. Statistical analysis was performed with Minitab ${ }^{\circledR}$ for Windows Release 11.1 (Minitab Inc., State College, PA, USA). The term "significant" (statistically significant) in the text means $p=0.05$.

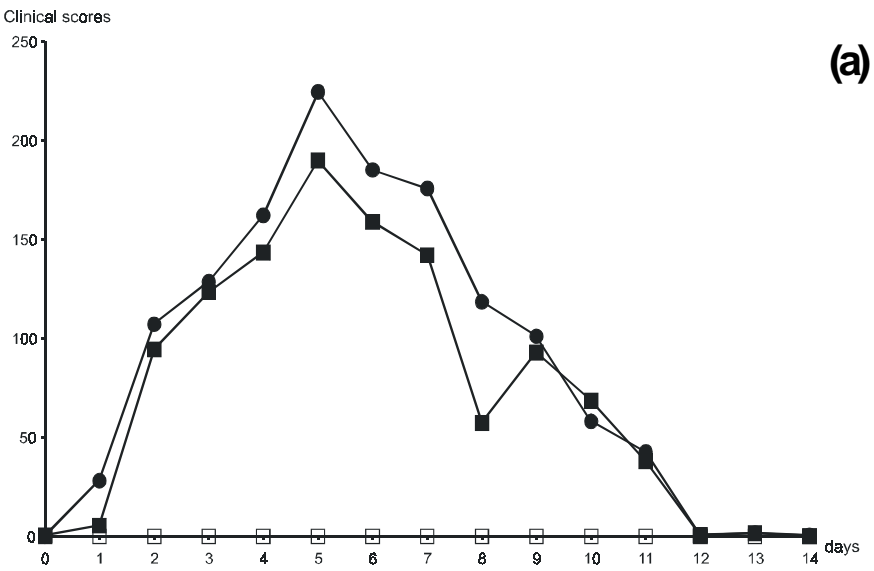

\section{RESULTS}

Genomic and antigenic analyses. Restriction enzyme analyses confirmed the subtyping of EVI 123/98 (BHV-1.1) and SV 265/96 (BHV-1.2a). Antigenic analyses with anti-BHV-1 Mabs (Souza et al. 2002) as well as with Mab 71 (Rijsewijk et al. 1999) again confirmed the antigenic differences between the two isolates of distinct subtypes (not shown).

Clinical findings following primary infection and reactivation. The calves infected either with EVI 123/98 or SV 265/96 showed severe signs of illness (Fig. 1a). The respiratory rates were significantly elevated from day 2 to 11 pi. On day 2 , the rectal temperatures of the infected calves started to rise (Fig. 2a). The highest temperatures were recorded on day 5. Fever $\left(=39,5^{\circ} \mathrm{C}\right)$ was recorded from day 2 to 7 in calves from both groups and respiratory rates accompanied such elevation (Fig. 3a). Apathy, anorexia, rhinitis with redness of the nasal mucosae, nasal and ocular discharges, formation of vesicles with tendency to coalesce and form erosions on the nasal mucosae, conjuntivitis, nasal stridor, sneezing and sponta-neous coughing were often observed in all calves. Enlar-gement of the retropharyngeal, submandibular and cervical lymphnodes were recorded from day 4 to day 12 after infection. Dyspnoea and tracheal stridors were observed in all calves although in different degrees. Despite severely ill on day 5 to $7 \mathrm{pi}$, all calves completely recovered from primary infection 10 days post-infection without noticeable sequels.

At reactivation, clearly noticeable signs of respiratory disease were again observed on both groups of infected calves (Fig. 1b, $2 b$ and $3 b)$. However, such signs were less intense than those observed during primary infection. Calves were pyrexic from day 1 to six pr (Fig. 2b). One of the BHV-1.2a-infected calves died on day $11 \mathrm{pr}$. This calf had low titres of infectious virus (10 to $10^{2.5} \mathrm{TCID}_{50}$ ) in the nasal hornets, trachea, lung, mediastinic and periportal lymphnodes, liver and spleen. Mild ganglioneuritis was evident in the trigeminal ganglia. Post-mortem examination

Fig. 1. Mean clinical scores attributed to calves after inoculation: (a) clinical scores at primary infection; (b) at reactivation. Full squares: BHV1.1; black circles: BHV-1.2a: empty squares: control calves. Clinical scores defined in methods. "Days" refers to days after infection (a) or following administration of dexamethasone (b).

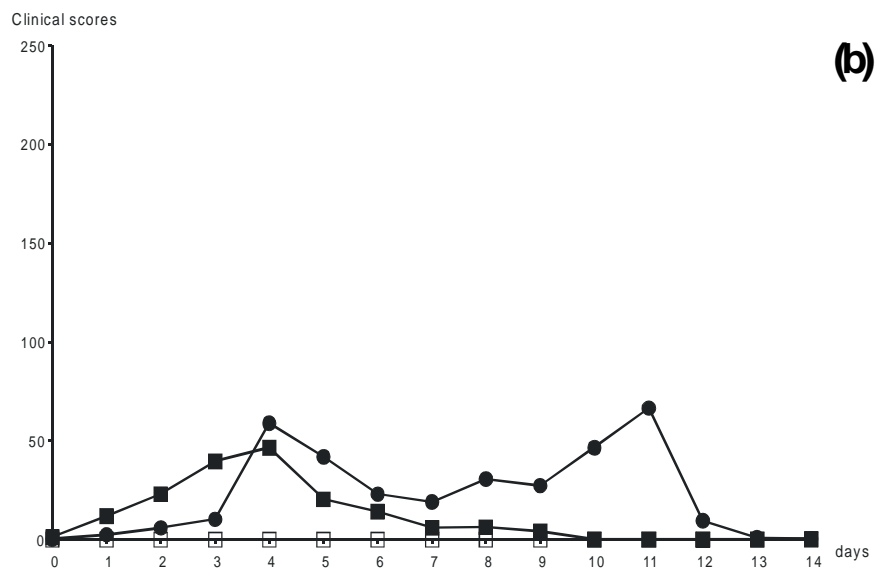



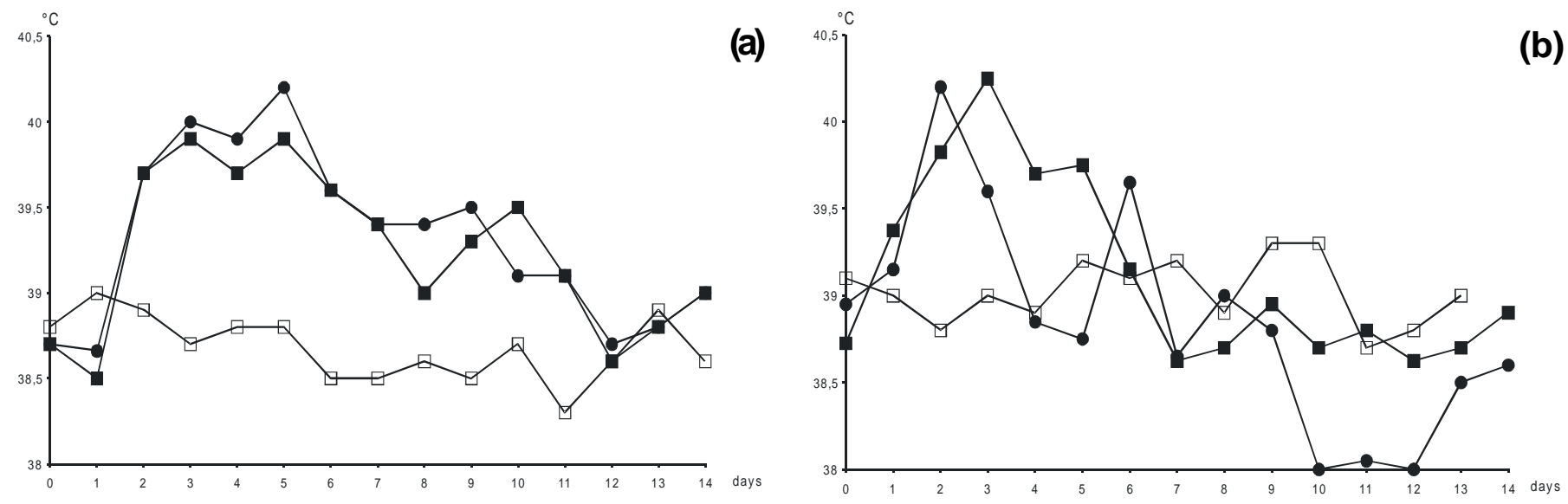

Fig. 2. Mean rectal temperatures of calves after inoculation: (a) at primary infection; (b) at reactivation. Full squares: BHV-1.1; black circles: BHV-1.2a; empty squares: control calves. "Days" refers to days after infection (a) or following administration of dexamethasone (b).

revealed mild pneumonia and focal hepatic necrosis. In such lesions, BHV-1 antigen was detected by immunohistochemistry. Escherichia coli and Klebsiella sp were isolated from the lungs.

Virus shedding following primary infection and reactivation. Virus of the expected subtype was isolated from nasal swabs from all infected calves from day 1 until day 14 pi, from calves in both groups (Fig. 4a). No cross-contamination was detected, neither after primary infection nor at reactivation, as evidenced by the differential IPMA (data not shown). The amounts of infectious virus shed by calves infected with BHV-1.1 were significantly higher than those from BHV-1.2a-infected calves in samplesfrom day 2 and 3 pi; after that period, both BHV-1.1 and BHV-1.2a were recovered to similar titres, up to day 14 pi. Ocular virus shedding was initially detected on day 1 pi on calf 127 (infected with BHV-1.2a), which shed a large amount of infectious virus $\left(10^{6.3} \mathrm{TCID}_{50} / \mathrm{mL}\right)$. However, all other calves started to shed virus by day 4 pi (Fig. 4b). Virus shedding was detected at least until day 14 pi, when sampling was discontinued (Fig. 4b).

At reactivation, nasal virus shedding was detected from day

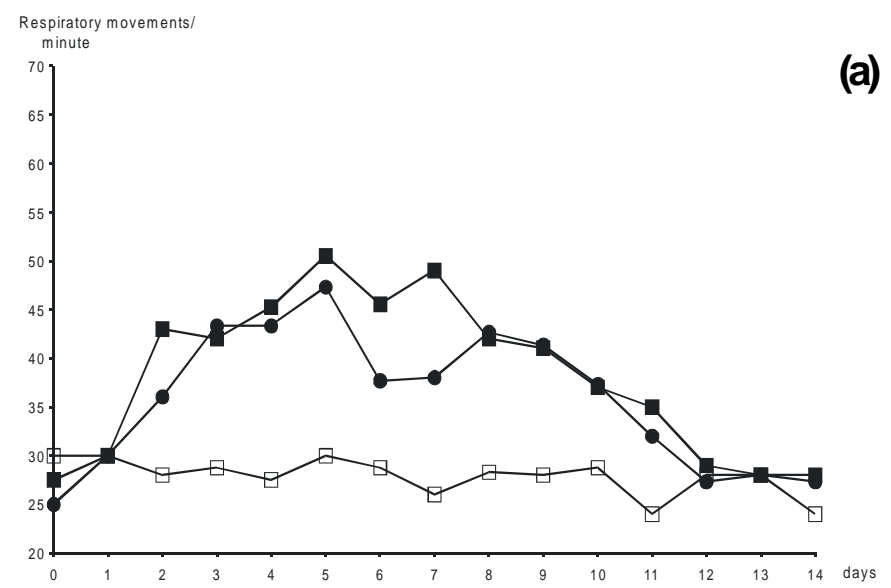

2 to 9 pr (Fig. 4b). Ocular virus shedding was detected from day 3 to 9 pr (Fig. 5b). Control calves were negative at virus isolation attempts throughout the experiment.

Neutralizing antibody responses. None of the calves had BHV-1 neutralizing antibodies previous to the experiments. On day 7 pi, low titres of neutralizing antibodies were present in three of the calves infected with BHV-1.1 and in two of the calves infected with BHV-1.2a. By day 14 pi, seroconversion was evident in all inoculated calves. Neutralizing antibody titres remained at low to moderate levels (above 1:16 or 1:1.2 $\log _{10}$ ) at least until day $30 \mathrm{pi}$, when sampling was discontinued (Fig. 6a). At reactivation, at 180 days pi, calves still had low to moderate levels of neutralizing antibodies, whose titres increased significantly on day 194 pi (Fig. 6b). Control calves remained negative for neutralizing antibodies throughout the experiment.

\section{DISCUSSION}

Both viruses inoculated in the presnt study (BHV-1.1 and

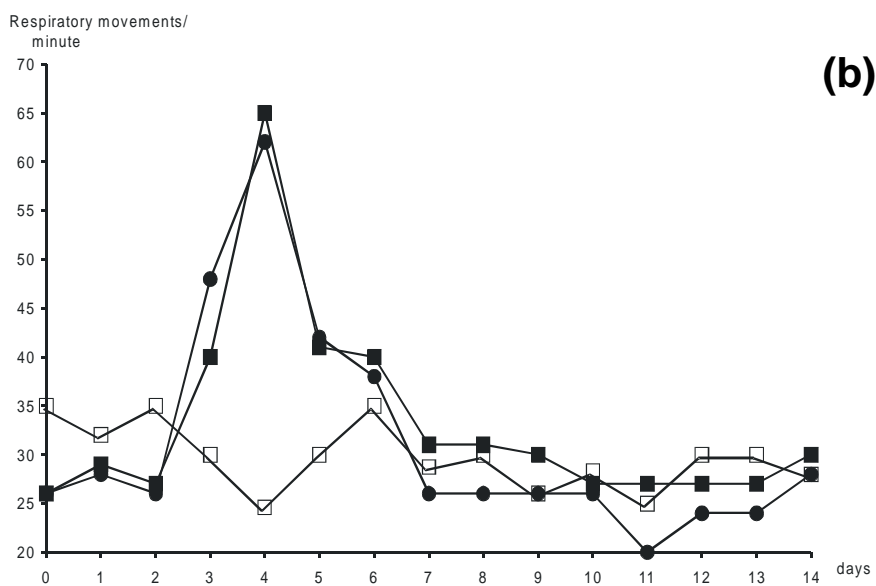

Fig. 3. Mean respiratory rates of calves after inoculation: (a) during primary infection; (b) at reactivation. Full squares: BHV-1.1; black circles: BHV-1.2a; empty squares: control calves. "Days" refers to days after infection (a) or following administration of dexamethasone (b). 

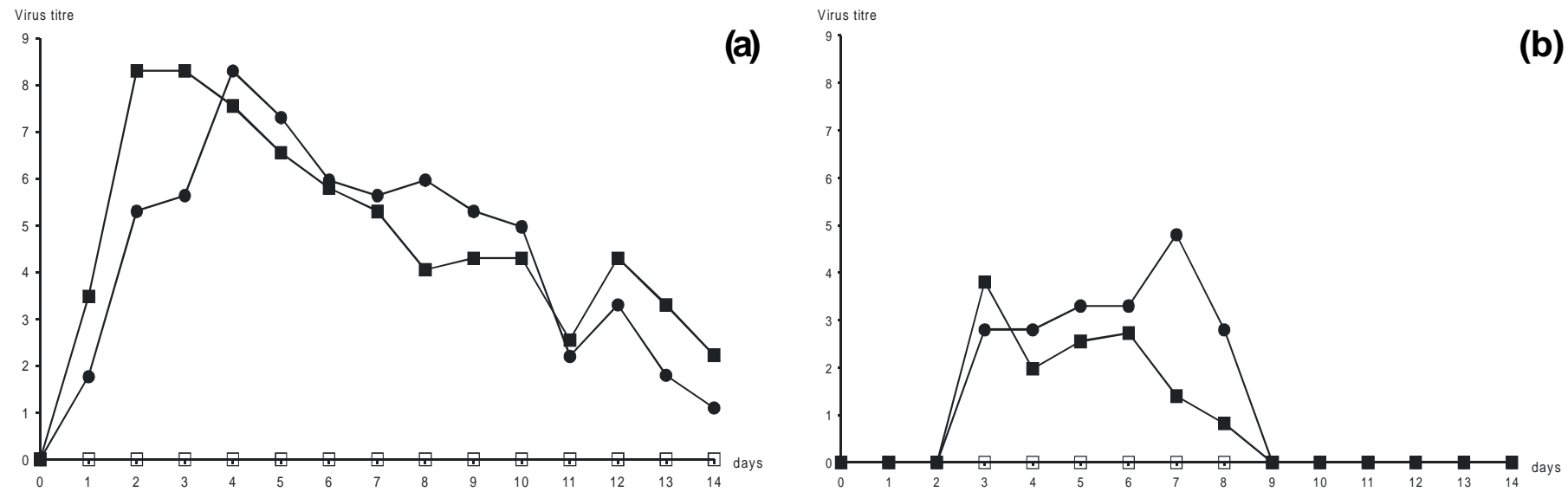

Fig. 4. Virus shedding during primary infection: (a) nasal; (b) ocular. Infectious virus titres calculated as the geometric mean titres for each group; expressed in $\log _{10} T C D_{50} / \mathrm{mL}$. Full squares: BHV-1.1; black circles: BHV-1.2a; empty squares: control calves. "Days" refers to days after infection (a) or following administration of dexamethasone (b).

BHV-1.2a) were highly virulent for 3 months old calves. Other researchers have met difficulties in experimentally reproducing BHV-1.1 clinical signs (Kaashoek 1995). Here, no difficulties were found in demonstrating the pathogenicity of both virus subtypes. It has been observed previously that the overall responsiveness of younger calves (2 weeks old or younger) to BHV-1 experimental infections may be highly variable (Kaashoek et al. 1994). On the other hand, calves older than 5 months seem less susceptible to infection (Msolla et al. 1983b). In view of that, and based on our own previous experience with BHV-1 inoculations, an option was made for conducting the experiments here described on three months old calves. This lead to more consistent and fairly reproducible findings, as revealed by the analysis of the outcome of the inoculations.

Viruses of both subtypes were shed with no significant differences in infectious titres and for similar lengths of time, except for a short period on the first 3 days pi. Virus shedding was also very similar to the results of Edwards et al. (1991) with BHV-1.1 and BHV-1.2b. The duration of virus shedding was slightly longer than observed by others when studying other bovine herpesvirus subtypes (Msolla et al. 1983b, Miller et al. 1991, Kaashoek et al. 1994, Meyer et al. 2001).

Regarding reactivation, both virus subtypes were reactivated with relative ease following dexamethasone administration, leading to the development of apparent signs of respiratory disease. at reactivation. Such as with primary acute infections, reactivation of BHV-1 latency have sometimes been difficult to reproduce experimentally (Edwards et al. 1990, Meyer et al. 2001). BHV-1 strains that apparently reactivate "more easily than others" have been documented (Kaashoek 1995). The viruses used in the present study may be more easily reactivated than those used in previous studies. As such viruses were chosen as representative of Brazilian BHV-1 isolates, it is possible that the viruses circulating in the country are more easily reativated than those used in previous studies. However,
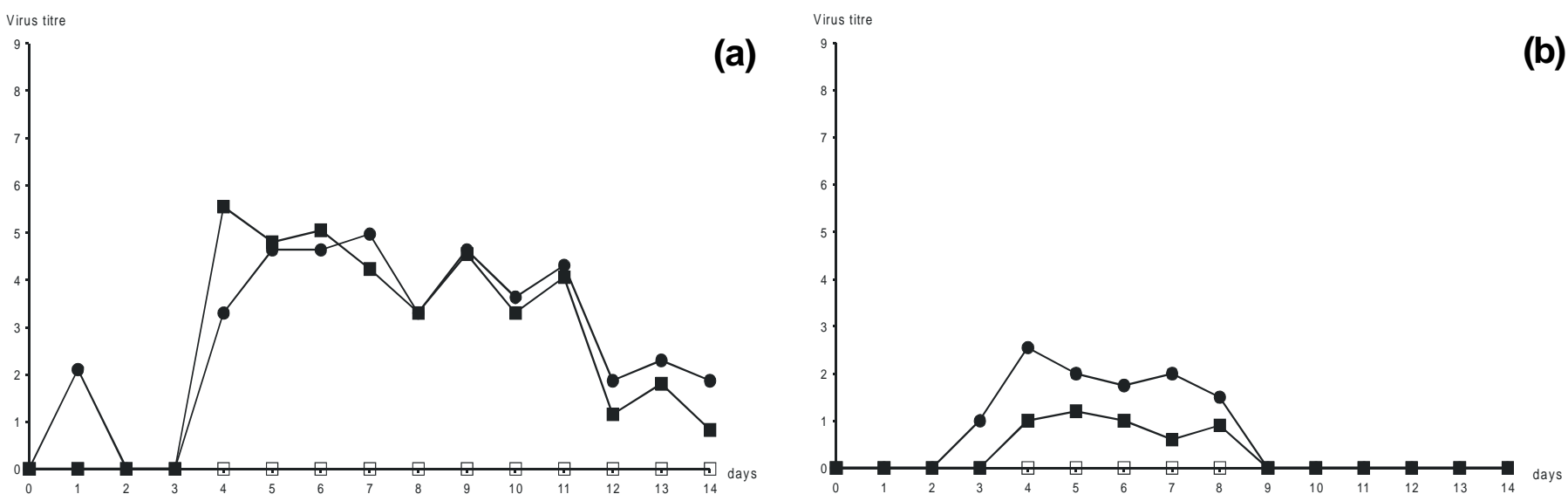

Fig. 5. Virus shedding at reactivation: (a) nasal; (b) ocular. Infectious virus titres calculated as the geometric mean titres for each group; expressed in $\log _{10} \mathrm{TCID}_{50} / \mathrm{mL}$. Full squares: BHV-1.1; black circles: BHV-1.2a; empty squares: control calves. "Days" refers to days after infection (a) or following administration of dexamethasone (b). 

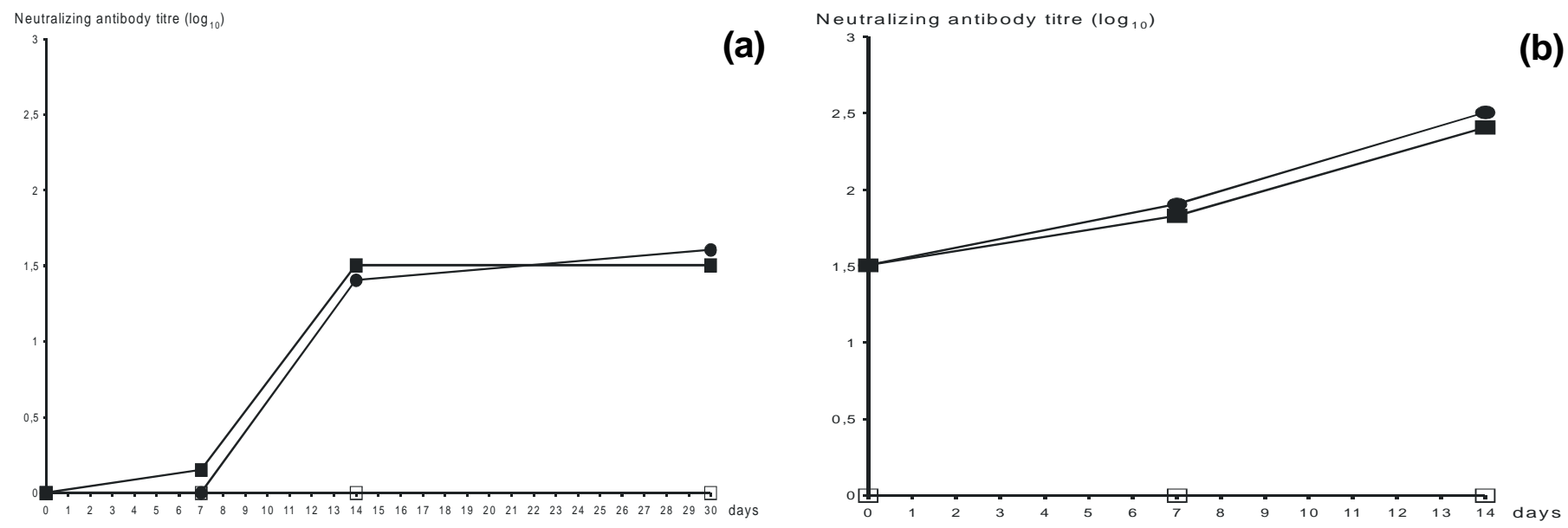

Fig. 6. Neutralizing antibodies (geometric mean titres in each group). Titres expressed as $\log _{10}$ of the reciprocal of the neutralizing antibody titre: (a) after inoculation; (b) at reactivation. Full squares: BHV-1.1; black circles: BHV-1.2a; empty squares: control calves. "Days" refers to days after infection (a) or following administration of dexamethasone (b).

it is also possible that other factors such as the age of calves at inoculation and the amount of virus inoculated may have had some influence on the pathogenicity following reactivation. Others have used either younger (Edwards et al. 1990) or older animals (Kaashoek 1995), while inoculating similar amounts of virus, both with varying levels of succes at reactivation. In the present study, both virus subtypes inoculated were similarly reactivated and caused no significantly different pathogenic effects on calves at reactivation. Likewise, viral excretion during reactivation was again similar in both groups. Nevertheless, despite the overall similar clinical scores, it is worth highlighting that one calf on the group infected with BHV-1.2a died on day 11 after reactivation. Histopathology and immunohistochemistry revealed that the most striking finding was the BHV-1-associated hepatic necrosis. Although such kind of lesion has often been reported on aborted foetuses and generalized BHV-1 infections in newborns (Gibbs \& Rweyemamu 1977), this is actually the first mention to such lesions in a 11 months old calf. However, it was beyond the scope of the present study to examine the pathogenesis of such lesion in more detail. It is possible that individual variability may have brought up such unexpected outcome, since all calves were kept under similar conditions throughout.

The present work demonstrated that a BHV-1.2a isolate was capable of inducing as intense respiratory illness for the respiratory tract as BHV-1.1. Both subtypes (BHV-1.1 and BHV1.2a) were able to induce clinically undistinguishable respiratory disease in calves, either subsequent to primary infection or following reactivation. At least with the viruses examined here, different subtypes were not paralleled by differences in pathogenicity for the respiratory tract.

Acknowledgements.- The authors thank Dr. Frans Rijsewijk (Wageningen University, Animal Sciences Group, Lelystad, The Netherlands) for kindly providing Mab 71. F.R.S. is in receipt of a CNPq grant from the Programa de Pós-graduação em Ciências Veterinárias (PPG-CIVET), UFRGS, RS, Brazil. E.F.F., R.W., D.D. and P.M.R. are CNPq research fellows. This work was supported by PRONEX, CNPq and FAPERGS.

\section{REFERENCES}

Collie D.D. 1992. Pulmonary function changes and clinical findings associated with chronic respiratory disease in calves. Brit. Vet. J. 148:3340.

D'Arce R.C.F., Almeida R.S., Silva T.C., Franco A.C., Spilki F., Roehe P.M. \& Arns C.W. 2002. Restriction endonuclease and monoclonal antibody analysis of Brazilian isolates of bovine herpesviruses types 1 and 5. Vet. Microbiol. 88:31534.

Edwards S., White H. \& Nixon P. 1990. A study of the predominant genotypes of bovid herpesvirus 1 isolated in the U.K. Vet. Microbiol. 22:213-223.

Edwards S., Newman R.H. \& White, H. 1991. The virulence of British isolates of bovid herpesvirus 1 in relationship to viral genotype. Brit. Vet. J. 147:216-231.

Gibbs E.P.J. \& Rweyemamu M.M. 1977. Bovine herpesviruses. Part I. Vet. Bull. 47:317-343.

House J.A. \& Baker J.A. 1971. Bovine herpesvirus IBR-IPV. The antibody virus neutralization reaction. Cornell Vet. 61:320-335.

Kaashoek M.J., Straver P.J., Rooj E.M.A. van, Quak J. \& Oirschot J.T. van 1994. Virulence, immunogenicity and reactivation of seven bovine herpesvirus 1.1 strains: clinical virological and haematological aspects. Vet. Microbiol. 139:416-421.

Kaashoek M.J. 1995. Marker vaccines against bovine herpesvirus type 1 infections. PhD Thesis, Utrecht University. $155 \mathrm{p}$.

Metzler A.E., Matile H., Gasman U., Engels M. \& Wyler R. 1985. European isolates of bovine herpesvirus 1: A comparison of restriction endonuclease sites, polypeptides and reactivity with monoclonal antibodies. Arch. Virol. 85:57-69.

Meyer G., Lemaire M., Ros C., Belak K., Gabriel A., Cassart D., Coignoul F., Belak S. \& Thiry E. 2001. Comparative pathogenesis of acute and latent infections of calves with bovine herpesvirus types 1 and 5 . Arch. Virol. 146:633-652.

Miller J.M., Whetstone C.A. \& Maaten M.J. van der 1991. Abortifacient properties of bovine herpesvirus type 1 isolates that represent three subtypes determined by restriction endonuclease analysis of viral DNA. Am. J. Vet. Res. 52:458-461.

Msolla P.M., Wisemann A., Allan E.M. \& Selman, I.E. 1983a. A comparison of cattle of three strains of infectious bovine rhinotracheitis virus (Strichten strain). Vet. Microbiol. 8:129-134.

Msolla P.M., Wisemann A., Allan E.M. \& Selman, I.E. 1983b. Experimental infection of cattle of different ages with infectious bovine rhinotracheitis virus (Strichten strain). J. Comp. Path. 93:205-210. 
Oirschot J.T. van 1995. Bovine herpesvirus in semen of bulls and the risk of transmission: a brief review. Vet. Quart. 17:29-33

Rijsewijk F.A.M., Kaashoek M.J., Langeveld J.P., Meloen R., Judek J., BienkowskaSzewczyk K., Maris-Veldhuis M.A. \& Oirschot J.T. van 1999. Epitopes on glycoprotein $\mathrm{C}$ of bovine herpesvirus-1 (BHV-1) that allow differentiation between BHV-1.1 and BHV-1.2 strains. J. Gen. Virol. 80:1477-1483.

Roehe, P.M.1991. Studies on the comparative virology of pestiviruses. Ph.D. Thesis, University of Surrey, Guilford, UK. 361 p.
Souza V.F., Melo S.V., Esteves P.A, Schmidt C.S., Gonçalves D.A., Schaefer R., Silva T.C., Almeida R.S., Vicentini F.K., Franco A.C., Oliveira E.A.S., Spilki F.R., Weiblen R., Flores E.F., Lemos R.A., Alfieri A.A., Pituco E.M. \& Roehe P.M. 2002. Caracterização de herpesvírus bovinos tipos 1 (BHV-1) e 5 (BHV-5) com anticorpos monoclonais. Pesq. Vet. Bras. 22:3-18.

Turin L., Russo S. \& Poli G. 1999. BHV-1: new molecular approaches to control a common and widespread infection. Molec. Med. 5:261284. 